\title{
The Six Pillars of Knowledge Economics
}

\author{
Carsten Brockmann \\ Capgemini Germany \\ Carsten.Brockmann@Capgemini.com
}

\begin{abstract}
The purpose of this paper is to extend our earlier work on the contributions to the mini-track on Knowledge Economics at the Hawaii International Conference on System Sciences (HICSS). In the present work, we analyze 16 contributions from 2012 to 2016 and based on our analysis, we propose the Six Pillars of Knowledge Economics framework. The proposed framework articulates that six elements are essential to generate knowledge outputs: Innovation Capability, Leadership, Human Capital, Information Technology Resources, Financial Resources, and Innovation Climate. Additional major findings are that organizations are the most common unit of analysis, while the individual level is hardly considered. Journals represent the major source of citations. Conference proceedings were less cited, though more current. We recommend major conferences to be indexed by services like Scopus and provide open access to peer-reviewed proceedings.
\end{abstract}

\section{Introduction}

Systematic reviews of published literature repositories are essential for any academic inquiry and research progress in a given field [1]. In essence, methodical analyses of published literature help to reveal what is already known and what needs to be addressed in future research projects. Familiarized with the status of the field by literature review papers, researchers are more effective in their own scholarly inquiries. They can avoid spending time and resources to examine what was already known, well researched and well accepted. In particular, literature review papers are crucial in fast growing disciplines as they channel the research efforts towards the most promising topics and so advance the body of knowledge building faster.

Within the current global economy, as more and more countries move to become knowledge economies and are dependent on knowledge outputs,

\author{
Narcyz Roztocki \\ State University of New York at New Paltz \\ Kozminski University \\ roztockn@newpaltz.edu
}

Knowledge Economics is a fast growing discipline. Knowledge Economics focuses on benefits and costs of generating knowledge outputs and is one of many subfields of the field of knowledge management.

The rising popularity and relevance in the current economy contributed to Knowledge Economics having its own dedicated mini-track at the Hawaii International Conference on System Sciences (HICSS). The HICSS Knowledge Economics minitrack was introduced in 2012 and throughout the years has attracted a variety of submissions. Since 2012, the mini-track co-chairs have created a one-page description of the papers [2-6]. Moreover, in 2014 they conducted and published an analysis of seven papers published in HISSS proceedings in years 2012 and 2013 [7].

In the meantime, the cumulative body of knowledge of the HICSS Knowledge Economics mini-track grew to 16 papers presented at the conference in five years and updated analysis is in order.

This updated analysis is presented in this contribution and its objective is to provide a robust foundation for scholars working in the field of Knowledge Economics and therefore help advance the field.

The three main research questions that guide this literature analysis are:

1. What are the main topics in the current Knowledge Economics research?

2. What gaps in current research exist and what are promising research avenues for the future?

3. What are the most crucial components in the process of creating knowledge outputs?

The remainder of the paper is structured as follows. In the next section, we briefly describe the background of Knowledge Economics. Then, we outline the methodology of our literature analysis. After summarizing the key results, we propose the Six Pillars of Knowledge Economics framework. Finally, we communicate several major observations and propose multiple future research avenues. 


\section{Background}

Knowledge Economics concerns the financial impact of knowledge creation, modification, distribution and use [7]. By analyzing business models of Enterprise Resource Planning (ERP) vendors, Brockmann found that knowledge can be monetized by offering customization of the standard systems. This customization allows ERP to be adjusted to the specific needs of an organization while creating an knowledge output and additional income streams for ERP vendors [8].

The expression Knowledge Economics contains two terms, knowledge and economics [7], and it is related to the generation of knowledge outputs of commercial value as depicted in Figure 1.

The first term, knowledge, is commonly believed to have been first defined by Davenport and Prusak [9]. According to Davenport and Prusak's definition, knowledge is an evolving mix of contextual information, framed experience, values and expert insight. This diverse mix provides a useful framework for storing, evaluating and using collected experiences and information. Moreover, these past experiences and information are often reflected in organizational documents as well as imbedded in organizational routines, business processes, practices, and values.

The second term economics, is defined by Colander [10] as how people coordinate their wants and desires given the social customs, decision-making mechanisms and political realities of the society. Mankiw [11] takes a different approach and defines economics as the study of how society manages its scarce resources. Bade and Parkin [12] consider economics as the study of human behavior, focusing on human decision-making.

Knowledge outputs could be tangible or intangible. Examples of tangible knowledge outputs are books and software. Examples of intangible knowledge outputs could be business consulting or professional editing.

Knowledge Economics deals with financial aspects of knowledge management [7]. For example, there are costs and benefits associated with knowledge management. Costs incurs for identification, capturing, storing, searching, and retrieving knowledge. Financial benefits of knowledge management include improved products and/or services and better decision-making. Overall, these costs and benefits of managing knowledge can be defined as Knowledge Economics [7].

Knowledge management, as defined by Jennex et al. $[13,14]$, is a process of the selective application of knowledge from past experiences of decision-making to current and future decision making activities with the intent of improving the organization's effectiveness. According to Jennex and Zyngier [15], knowledge management is a vehicle to increase the use of knowledge within organizations by applying the methodical processes of knowledge identification, capture, storage, search, and retrieval. It is also based on processes that facilitate the transfer of knowledge from those who generate it to those who use it to make decisions.

Knowledge management is not always the same and must be tailored to a given organization. Human capital of employees and competency of management are essential in this aspect. The most challenging is proper knowledge management in organizations that operate in a fast-changing business and regulatory environment and are plagued by "fragile human capital" [16] while having problems with marketing theirown knowledge outputs [17].

Our definition is as follows: Knowledge Economics is a research field that concerns factors and activities aiming to generate knowledge outputs. The knowledge outputs are objects of commercial value and are generated in knowledge-intensive activities or processes by using knowledge creation or modification. Knowledge Economics also deals with distribution and use of knowledge outputs.

Knowledge Economics consists of two perspectives: a macro-perspective analyzing factors that positively influence the quantity and quality of knowledge outputs in a society, and a microperspective which analyzes the handling of knowledge objects in individual transactions. Herein, the capturing, storing, searching and retrieving of knowledge outputs are subjects of interest.

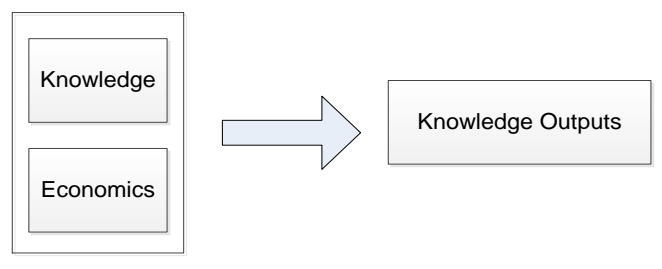

Figure 1: Definition of Knowledge Economics

\section{Methodology}

In order to examine the cumulative body of knowledge of the past accepted submissions to the HICSS mini-track on Knowledge Economics a systematic analysis was used. In essence, the same methodology was used as in our earlier study [7].

Since the inception the HICSS mini-track on Knowledge Economics in 2012, 16 manuscripts have passed the rigorous peer review process and were 
included in the HICSS proceedings. All these papers were considered for our examination:

From 2012: Chung et al. [18], Rai [19] and Trauth [20] From 2013:Bahrs et al. [21], Loeser et al. [22], Prpic and Shukla [23] and Thies and Stanoevska-Slabeva [24]

From 2014: Brockmann and Roztocki [7], Prpic and Shukla [25] and Sharif et al. [26]

From 2015: Brockmann and Roztocki [27], Hilbert [28] and Kees [29]

From 2016: Al Busadi [30], Kowal and Gurba [31] and Peinl et al. [32]

Similar to our earlier analysis [7], the 16 papers of in the HICSS mini-track Knowledge Economics were analyzed in four major steps regarding dimensions depicted in Figure 2.



Figure 2: Steps of literature analysis undertaken (adapted from Brockmann and Roztocki (2014))

\section{Results}

\subsection{Citation Analysis}

In the first step of our analysis, we examined the theoretical foundation of the 16 papers published in the years 2012-2016. In essence, we looked at characteristics of sources included in the reference sections. In order to efficiently analyze the reference sections of the 16 papers, we decided to use the service provided by Scopus. Scopus is a bibliographic database containing citations for academic articles. In addition to academic journals, many prestigious conferences, such as HICSS, are referenced in Scopus. Scopus allows downloading references in CSV text file format.

In total, the 16 papers published in the years 20122016 contained 656 citations of which 590 were unique. In other words, authors of 16 papers presented in the HICSS mini-track on Knowledge Economy build their research on a cumulative body of 590 sources. The number of citations per paper ranged from 23 to 62 . The average number of citations per paper was 41 and the median 43 .

The analyzed papers used a variety of sources as shown in Table 1. It can be observed that more than half of the overall citations are based on journal articles, followed by books and conference proceedings. The other sources included trade publications, web sites and working papers. In line with our earlier analysis [7], this confirms our conclusion that authors wishing to disseminate their ideas in the field of Knowledge Economics should strive mostly for journal publications. As a next step, they should proceed by publishing their ideas in the proceedings of the leading conferences. In contrast, the effort of publishing in trade publication, websites and working paper is not rewarded at all by the research community.

\section{Table 1: Distribution of sources}

\begin{tabular}{|l|r|}
\hline Type of source & Percentage \\
\hline Journals & 51.2 \\
\hline Books & 20.0 \\
\hline Conference Proceedings & 13.9 \\
\hline Others & 14.9 \\
\hline
\end{tabular}

Again, since the majority of publications cited were published in journals, a deeper analysis of journals was performed as in our earlier analysis [7].

Table 2: Frequency of cited journal

\begin{tabular}{|l|r|}
\hline Source title & Count \\
\hline MIS Quarterly & 24 \\
\hline Strategic Management Journal & 16 \\
\hline Journal of Management Information & 14 \\
Systems & 14 \\
\hline Organization Science & 9 \\
\hline International Journal of Knowledge & \\
Management & 7 \\
\hline Journal of Strategic Information & 6 \\
\hline Systems & 6 \\
\hline Information and Management & \\
\hline Research Policy & \\
\hline
\end{tabular}

Table 2 shows that only eight journals account for 96 of the cited articles. This represents about 14.6 percent of all 656 citations. After looking at the journals, it can be concluded that the sources are dominated by two streams: management literature and 
IT literature. It can also be observed that authors who would like to see their work cited should submit their work to one of the journals listed in Table 2 .

Table 3 shows how current publications from their respective outlets were. The second column of Table 3 depicts the average year of publication and the second column. It is observable that conference papers provide the most current theoretical insights. Moreover, a closer examination of conference publications shows that most of the cited conference proceeding originated from the AMCIS and HICSS. Once the ideas have matured through the discussions during conferences, they are published in journals and, perhaps, afterwards in a book.

Table 3: Kind of outlet and year published

\begin{tabular}{|l|r|r|}
\hline Kind of outlet & \multicolumn{1}{|c|}{ Average } & \multicolumn{1}{l|}{ Median } \\
\hline Journals & 2001.6 & 2005 \\
\hline Books & 1996.3 & 2000 \\
\hline Conference Proceedings & 2009.8 & 2011 \\
\hline Others & 2005.9 & 2008 \\
\hline
\end{tabular}

Table 4 depicts sources that were cited at least three times.

Table 4: Most cited work

\begin{tabular}{|l|r|}
\hline Source & Cited \\
\hline $\begin{array}{l}\text { Nonaka I., Takeuchi H. The Knowledge- } \\
\text { Creating Company (1995) [33] }\end{array}$ & 6 \\
\hline $\begin{array}{l}\text { Nonaka I. A Dynamic Theory of } \\
\text { Organizational Knowledge Creation (1994) }\end{array}$ & 5 \\
[34] & \\
\hline $\begin{array}{l}\text { Alavi M., Leidner D.E. Review: } \\
\text { Knowledge Management and Knowledge } \\
\text { Management Systems: Conceptual }\end{array}$ & 4 \\
$\begin{array}{l}\text { Foundations and Research Issues (2001) } \\
\text { [35] }\end{array}$ & \\
\hline $\begin{array}{l}\text { Powell W.W., Snellman K. W.W. Powell } \\
\text { The Knowledge Economy (2004). [36] }\end{array}$ & 4 \\
\hline $\begin{array}{l}\text { Brockmann C., Roztocki N. The Evolution } \\
\text { of Knowledge Economics through the } \\
\text { Course of Time - An Analysis of the }\end{array}$ & 3 \\
HICSS Minitrack (2014) [7] & \\
\hline $\begin{array}{l}\text { Hayek F.A. The Use of Knowledge in } \\
\text { Society (1945) [37] }\end{array}$ & 3 \\
\hline $\begin{array}{l}\text { Nonaka I., Toyama R. The } \\
\text { Knowledge-Creating Theory Revisited: } \\
\text { Knowledge Creation as a Synthesizing } \\
\text { Process (2003) [38] }\end{array}$ & 3 \\
\hline $\begin{array}{l}\text { Polanyi M. The Tacit Dimension } \\
\text { (1966) [39] }\end{array}$ & 3 \\
\hline
\end{tabular}

As it could be seen from Table 4, Ikujiro Nonaka is the most influential author in our sample based on the amount of citations.

From the contributions published, Alavi and Leidner (2011) as well as Brockmann and Roztocki (2014) were literature review papers. The fact that only two review papers were cited in our sample may indicate that the field of Knowledge Economics is being formed at the moment.

The most cited literature is relatively old and only one source from 2014 is more recent.

\subsection{Objectives and Methodologies Used}

In the second step, we examined the objectives of the 16 papers. Often, the purpose of the papers was pronounced in the abstract or introduction. We also looked at the research methodologies used by authors. Table 5 depicts the objectives and applied methodologies of the examined work. It can be observed that most of the papers are conceptual.

Table 5: Objectives and methodologies

\begin{tabular}{|l|l|l|}
\hline Paper & Objective & $\begin{array}{l}\text { Type of the } \\
\text { study }\end{array}$ \\
\hline Chung et al. & $\begin{array}{l}\text { To examine the } \\
\text { role of } \\
\text { organizational } \\
\text { agility as a } \\
\text { mediator } \\
\text { between } \\
\text { knowledge } \\
\text { creation } \\
\text { processes and } \\
\text { financial firm } \\
\text { performance }\end{array}$ & \\
\hline Rai [19] & $\begin{array}{l}\text { Determine the } \\
\text { gap between } \\
\text { perceptions of } \\
\text { importance and } \\
\text { knowledge in } \\
\text { Information } \\
\text { Technology (IT) } \\
\text { skills among } \\
\text { accountants in } \\
\text { Australia }\end{array}$ \\
\hline Trauth [20] & $\begin{array}{l}\text { Determine } \\
\text { process } \\
\text { knowledge of } \\
\text { acquisition, } \\
\text { production, and } \\
\text { transfer } \\
\text { management }\end{array}$ & \\
\hline
\end{tabular}




\begin{tabular}{|c|c|c|}
\hline Paper & Objective & $\begin{array}{l}\text { Type of the } \\
\text { study }\end{array}$ \\
\hline $\begin{array}{l}\text { Bahrs et al. } \\
{[21]}\end{array}$ & $\begin{array}{lr}\text { Introduce } & \text { two } \\
\text { opposing } & \\
\text { approaches for } \\
\text { the design of } \\
\text { knowledge } & \\
\text { transfer } & \end{array}$ & Empirical \\
\hline $\begin{array}{l}\text { Loeser et al. } \\
{[22]}\end{array}$ & $\begin{array}{l}\text { Propose a green } \\
\text { IS strategy }\end{array}$ & Theoretical \\
\hline $\begin{array}{l}\text { Prpic and } \\
\text { Shukla [23] }\end{array}$ & $\begin{array}{l}\text { Outline the } \\
\text { overarching } \\
\text { theory of crowd } \\
\text { capital }\end{array}$ & Theoretical \\
\hline $\begin{array}{l}\text { Thies and } \\
\text { Stanoevska- } \\
\text { Slabeva [24] }\end{array}$ & $\begin{array}{l}\text { Identifying the } \\
\text { state of the art in } \\
\text { environmental } \\
\text { reporting, } \\
\text { extracting the } \\
\text { requirements for } \\
\text { information } \\
\text { quality } \\
\text { environmental in } \\
\text { reporting, and } \\
\text { proposing an } \\
\text { approach of how } \\
\text { the quality of } \\
\text { environmental } \\
\text { information in } \\
\text { IO-ERIS can be } \\
\text { enhanced the } \\
\text { following } \\
\text { design science } \\
\text { research cycle. }\end{array}$ & Theoretical \\
\hline $\begin{array}{l}\text { Brockmann } \\
\text { and } \\
\text { Roztocki. [7] }\end{array}$ & $\begin{array}{l}\text { Evolution of the } \\
\text { emerging } \\
\text { research field on } \\
\text { knowledge } \\
\text { economics }\end{array}$ & $\begin{array}{l}\text { Theoretical } \\
\text { and empirical }\end{array}$ \\
\hline $\begin{array}{l}\text { Prpic and } \\
\text { Shukla [25] }\end{array}$ & $\begin{array}{l}\text { Define the term } \\
\text { crowd capability }\end{array}$ & Theoretical \\
\hline $\begin{array}{l}\text { Sharif et al. } \\
{[26]}\end{array}$ & $\begin{array}{l}\text { Apply cognitive } \\
\text { techniques for } \\
\text { knowledge-based } \\
\text { decisions. }\end{array}$ & Theoretical \\
\hline $\begin{array}{l}\text { Brockmann } \\
\text { and Roztocki } \\
{[27]}\end{array}$ & $\begin{array}{l}\text { Analyze articles } \\
\text { published in the } \\
\text { International } \\
\text { Journal of } \\
\text { Knowledge } \\
\text { management }\end{array}$ & $\begin{array}{l}\text { Theoretical } \\
\text { and empirical }\end{array}$ \\
\hline Hilbert [28] & $\begin{array}{l}\text { Creation of a } \\
\text { mathematical } \\
\text { framework } \\
\text { consider }\end{array}$ & Theoretical \\
\hline
\end{tabular}

\begin{tabular}{|c|c|c|}
\hline Paper & Objective & $\begin{array}{l}\text { Type of the } \\
\text { study }\end{array}$ \\
\hline & $\begin{array}{l}\text { economics and } \\
\text { technical } \\
\text { information } \\
\text { systems }\end{array}$ & \\
\hline Kees [29] & $\begin{array}{l}\text { Creation of a } 4- \\
\text { pillar model to } \\
\text { describe the } \\
\text { knowledge based } \\
\text { enterprise } \\
\text { organization }\end{array}$ & Theoretical \\
\hline $\begin{array}{ll}\text { Al } & \text { Busadi } \\
{[30]} & \end{array}$ & $\begin{array}{l}\text { Examine the } \\
\text { value of } \\
\text { information and } \\
\text { communications } \\
\text { technologies on } \\
\text { developing } \\
\text { knowledge } \\
\text { economies Gulf } \\
\text { Cooperation } \\
\text { Council } \\
\text { countries. }\end{array}$ & Empirical \\
\hline $\begin{array}{l}\text { Kowal and } \\
\text { Gurba [31] }\end{array}$ & $\begin{array}{l}\text { Examine } \\
\text { mobbing and } \\
\text { professional } \\
\text { burnout among } \\
\text { knowledge } \\
\text { workers in } \\
\text { transition } \\
\text { economies }\end{array}$ & Empirical \\
\hline $\begin{array}{l}\text { Peinl et al. } \\
{[32]}\end{array}$ & $\begin{array}{l}\text { Modeling of } \\
\text { knowledge and } \\
\text { business } \\
\text { processes }\end{array}$ & Empirical \\
\hline
\end{tabular}

\subsection{Data Source and Unit of Analysis}

In the third step of our analysis, we examined the papers for their data sources and unit of analysis. The results are presented in Table 6. It seems that most of the researchers validate their concepts in practice prior to publishing them. However, several contributions were conceptual, without any empirical validation.

The most frequently used unit of analysis is, with some exceptions, organization. 
Table 6: Data source and unit of analysis

\begin{tabular}{|c|c|c|}
\hline Paper & $\begin{array}{l}\text { Data } \\
\text { source }\end{array}$ & Unit of analysis \\
\hline $\begin{array}{l}\text { Chung et al. } \\
{[18]}\end{array}$ & Survey & Organization \\
\hline Rai [19] & Survey & Individual \\
\hline Trauth [20] & $\begin{array}{l}\text { Focus } \\
\text { Groups, } \\
\text { Interviews, } \\
\text { Survey }\end{array}$ & Region \\
\hline $\begin{array}{l}\text { Bahrs et al. } \\
\text { [21] }\end{array}$ & Interviews & Organization \\
\hline $\begin{array}{l}\text { Loeser et al. } \\
{[22]}\end{array}$ & Literature & Organization \\
\hline $\begin{array}{l}\text { Prpic and } \\
\text { Shukla. [23] }\end{array}$ & Literature & Organization \\
\hline $\begin{array}{l}\text { Thies and } \\
\text { Stanoevska- } \\
\text { Slabeva } \\
{[24]}\end{array}$ & $\begin{array}{l}\text { Case } \\
\text { studies }\end{array}$ & Organization \\
\hline $\begin{array}{l}\text { Brockmann } \\
\text { and } \\
\text { Roztocki[7] }\end{array}$ & Literature & $\begin{array}{l}\text { Conference } \\
\text { contributions }\end{array}$ \\
\hline $\begin{array}{l}\text { Prpic and } \\
\text { Shukla [25] }\end{array}$ & Literature & Literature analysis \\
\hline $\begin{array}{l}\text { Sharif et al. } \\
{[26]}\end{array}$ & Literature & Organization \\
\hline $\begin{array}{l}\text { Brockmann } \\
\text { and } \\
\text { Roztocki } \\
{[27]}\end{array}$ & Literature & Journal Articles \\
\hline Hilbert [28] & Literature & Organization \\
\hline Kees [29] & Literature & Organization \\
\hline $\begin{array}{l}\text { Al Busadi } \\
{[30]}\end{array}$ & $\begin{array}{l}\text { Secondary } \\
\text { data } \\
\text { (World } \\
\text { Bank) }\end{array}$ & Country \\
\hline $\begin{array}{l}\text { Kowal and } \\
\text { Gurba [31] }\end{array}$ & Survey & Individual/Organization \\
\hline $\begin{array}{ll}\text { Peinl } & \text { et } \\
\text { al.[32] } & \end{array}$ & Interviews & Organization \\
\hline
\end{tabular}

\subsection{Recommendations for Future Research}

In the fourth and final step, we examined the 16 papers for authors' recommendations regarding future research possibilities.

Overall, regarding the future research, most of the authors wish to validate and refine their concepts by conducting supplementary experiments, as shown in Table 7.
Table 7: Recommended future research

\begin{tabular}{|c|c|}
\hline Paper & Recommended future research \\
\hline $\begin{array}{l}\text { Chung et al. } \\
{[18]}\end{array}$ & Conduct more research \\
\hline Rai [19] & Replicate the current study \\
\hline Trauth [20] & esting \\
\hline $\begin{array}{lll}\text { Bahrs } & \text { et al. } \\
{[21]} & & \end{array}$ & $\begin{array}{l}\text { Merge the strings of research and } \\
\text { enhance the modeling language } \\
\text { to reflect risks and benefits }\end{array}$ \\
\hline $\begin{array}{l}\text { Loeser et al. } \\
{[22]}\end{array}$ & $\begin{array}{l}\text { Conduct empirical research to } \\
\text { validate the theoretically derived } \\
\text { model }\end{array}$ \\
\hline $\begin{array}{l}\text { Prpic and } \\
\text { Shukla [23] }\end{array}$ & Develop testable propositions \\
\hline $\begin{array}{l}\text { Thies and } \\
\text { Stanoevska- } \\
\text { Slabeva [24] }\end{array}$ & $\begin{array}{l}\text { Collect empirical data from } \\
\text { ongoing user evaluation }\end{array}$ \\
\hline $\begin{array}{l}\text { Brockmann } \\
\text { and Roztocki. } \\
\text { [7] }\end{array}$ & $\begin{array}{l}\text { Broaden scope and consider } \\
\text { emerging economies }\end{array}$ \\
\hline $\begin{array}{l}\text { Prpic and } \\
\text { Shukla [25] }\end{array}$ & $\begin{array}{l}\text { Investigate relative efficacy of } \\
\text { episodic structures vs. } \\
\text { constituting forms. }\end{array}$ \\
\hline $\begin{array}{l}\text { Sharif et al. } \\
{[26]}\end{array}$ & Extend the scope \\
\hline $\begin{array}{l}\text { Brockmann } \\
\text { and Roztocki } \\
\text { [27] }\end{array}$ & vledge society \\
\hline Hilt & $\begin{array}{l}\text { More research on short- and } \\
\text { long-term patterns. }\end{array}$ \\
\hline Kees & $\begin{array}{l}\text { Validate the developed approach } \\
\text { in other organization }\end{array}$ \\
\hline Al Busadi [30] & $\begin{array}{lc}\text { Conduct a more } & \text { sophisticated } \\
\text { econometric } & \text { longitudinal } \\
\text { analyses of World Bank data }\end{array}$ \\
\hline $\begin{array}{l}\text { Kowal and } \\
\text { Gurba [31] }\end{array}$ & $\begin{array}{l}\text { Consider socio-economic factors } \\
\text { such personal income. Expand } \\
\text { scope of investigation beyond } \\
\text { Poland }\end{array}$ \\
\hline [32] & $\begin{array}{l}\text { Performing end user evaluation } \\
\text { with a mobile modeling tool }\end{array}$ \\
\hline
\end{tabular}




\section{The Six Pillars of Knowledge Economics}

In 2004, in a working paper, Goel et al. [40] advised that in order to move a country towards becoming a knowledge economy four key strategic reforms are needed. These reforms should create a knowledge economy supported by the following four pillars: policy and institutional framework, innovation systems, education and training, and information infrastructure. This concept also emphasizes knowledge as critical element for economic performance at a country level. It is an interesting concept, but in our opinion, economic strength depends not only on only the creating but also the selling of knowledge outputs of commercial value. In addition, the definition by Goel et al. [40] discards the impact of resources and leadership, which are crucial.

The analysis of the 16 papers within the mini-track seems to supports our concept and resulted in the construction of a conceptual framework, which we have termed the Six Pillars of Knowledge Economics framework (Figure 3). The proposed framework focuses on marketable knowledge outputs and points to the most crucial components in the process of creating these knowledge outputs. In essence, in order to create knowledge outputs of commercial value, innovation capability, leadership, human capital, IT resources, financial resources, and innovation climate are required as depicted in Figure 3.

The first pillar of our Six Pillars of Knowledge Economics framework is innovation capability. In context of this work and based on the definition provided by Francis in 2005 [41], we define innovation capability as the ability to generate novel, potentially value-adding initiatives. In this definition, we use the word novel to underscore innovation content, meaning that it represents something that was not done before in a given environment. In addition, the initiative must have true potential to be valueadding, which means marketable.

The second pillar of our Six Pillars of Knowledge Economics framework is leadership. It is apparent that the owners are in position to control the strategy, allocation of resources, various initiatives [42] and creation of knowledge products and services.

The third pillar in our framework is human capital. Human capital is defined as abilities, skills and attitudes to produce economic value [43]. A highly talented, well-educated and creative workforce is more likely to generate knowledge products and services that could be marketed at a high premium. In contrast, creating knowledge economies based on knowledge outputs is difficult in countries where a large portion of the workforce is considered to represent "fragile human capital" $[16,44]$.
IT resources are the fourth pillar in our Six Pillars of Knowledge Economics framework. These IT resources, hardware, software and telecommunications networks are supportive in creating and marketing knowledge outputs.

Financial resources are the fifth pillar in our framework. Financial resources are enablers in generating knowledge outputs.

The sixth and last pillar in our framework is an innovative climate. All innovations begin with a novel ideas [45]. Some climates are supportive and some are hampering to creative ideas.

The proposed framework can be used to determine reasons why the knowledge outputs of commercial value are not at the level desired. One example could be that weak Leadership and insufficient Innovation Capability hinder the creation of knowledge outputs.

\section{Discussion}

In general, our analysis underscores the novelty of the field of Knowledge Economics. For example, it confirms no dominant themes or schools seem to exist. The field is dominated by mainstream journals where mostly US-based scholars publish their work. Frequently, these mainstream journals do not have Associate Editors or members of Editorial Board that are affiliated with institutions located in transition economies or other emerging regions [46].

Although the ideas presented in this paper are limited to only 16 papers presented at five consecutive HICSS conferences (HICSS 2012 to 2016), we feel that our analysis makes a reasonable contribution to the raising field of Knowledge Economics. Mainly, our paper presents several interesting observations that could be transformed in future research.

By using the citation analysis, we were able to detect that the AMCIS and the HICSS are the most relevant venues related to Knowledge Economics.

Moreover, our experience shows that a conference from which articles are highly cited should be indexed in a bibliographic database containing citations, such as Scopus. This provides opportunity to find articles and analyze their relationship.

The literature base aside from conferences can be regarded as established. Three examples are the citation from 1911 of Taylor [47], the citation from 1937 of Coase [48] and the citation from 1945 of Hayek [37]. Interestingly, there is one citation from 1941 by Kolmogorov [49].

Most researchers in the Knowledge Economics field focus on organizational implications of the knowledge management method. 


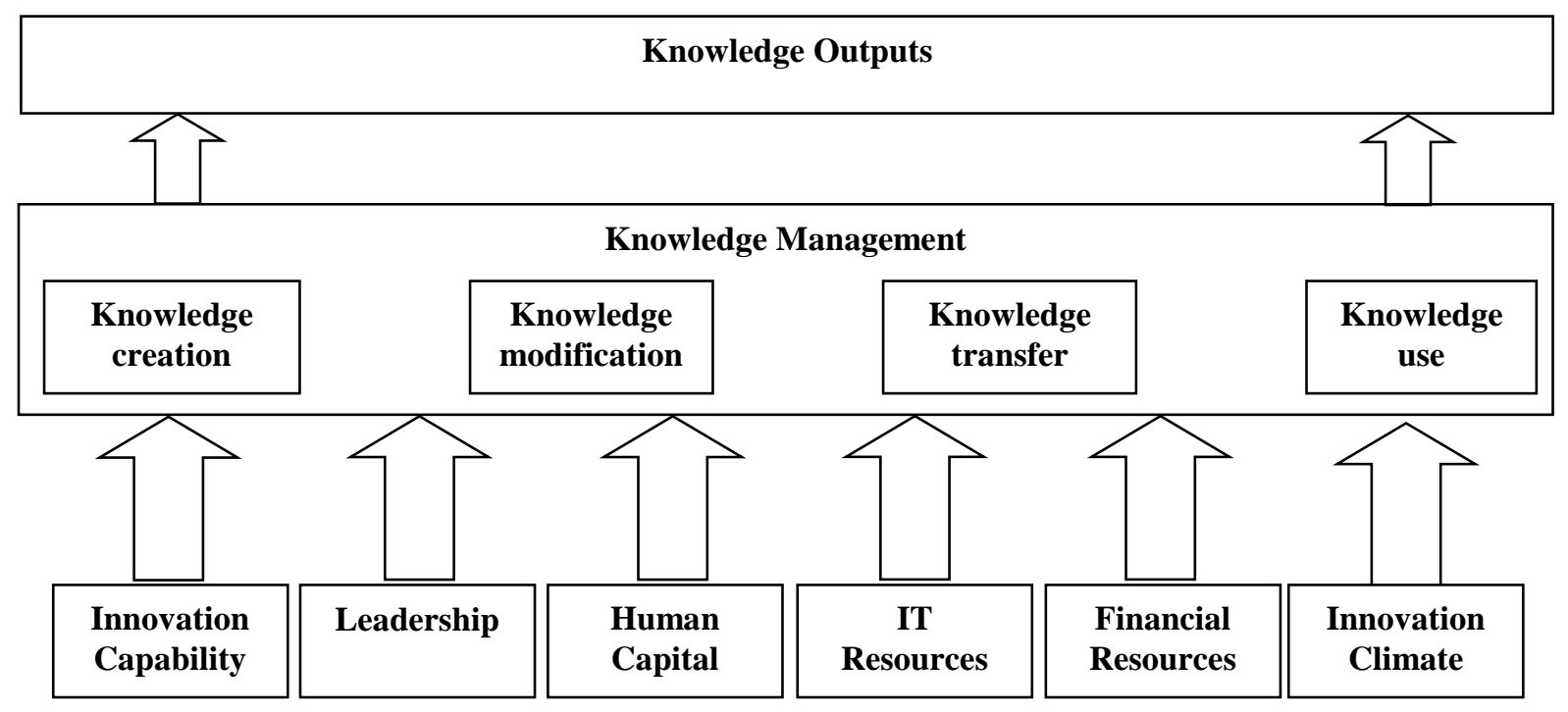

Figure 3: The six pillars of knowledge economics

\section{Limitations and Future Research}

As every academic work, our analysis is subject to limitations. Primarily, most of the conclusions are derived from an analysis of 16 papers presented in one mini-track. This limitation can be addressed by the inclusion of more papers. This expansion of the sample may include contributions presented at the various HICSS tracks and other conferences, such as AMCIS. The expanded sample may also contain journal publications, indexed in Scopus. Secondary, the proposed Six Pillars of Knowledge Economy framework is derived from only 16 contributions and should be validated empirically.

Two of the three papers presented at the HICSS-49 conference move the scope of investigation to emerging economies: Poland and the Gulf Cooperation Council (GCC) countries: Bahrain, Kuwait, Oman, Qatar, Saudi Arabia and the United Arab Emirates. These regions are in the need of new approaches and new business models and academic research is crucial for development [50,51].

In regard to our observations derived from analysis, further research may be done on the individual and group level. Research projects at the country level have great potential, especially research that examines Knowledge Economics in emerging economies. Many of these emerging economies tend to import knowledge products and innovation is weak despite the availability of local talents [52].

In summary, we believe that the review of HICSS contributions related to and the proposed Six Pillars of
Knowledge Economics framework provide a robust foundation for future research in this field.

\section{References}

[1] J. Webster and R.T. Watson, "Analyzing the Past to Prepare for the Future: Writing a Literature Review," MIS Quarterly, 26(2), pp. xiii-xxiii, 2002.

[2] C. Brockmann and N. Roztocki, "Economics of Knowledge Management and Transfer - Minitrack Introduction " in 45th Hawaii International Conference for System Sciences (HICSS), Wailea, USA, 2012, p. 3611.

[3] C. Brockmann and N. Roztocki, "Knowledge Economics Minitrack Introduction " in 46th Hawaii International Conference for System Sciences (HICSS), Wailea, USA, 2013, p. 3494.

[4] C. Brockmann and N. Roztocki, "Knowledge Economics Minitrack Introduction " in 47th Hawaii International Conference on Systems Sciences (HICSS), Big Island, USA, 2014, p. 3460.

[5] C. Brockmann and N. Roztocki, "Knowledge Economics: Research Advances " in 48th Hawaii International Conference on Systems Sciences (HICSS), Kauai, USA, 2015, p. 3821.

[6] C. Brockmann and N. Roztocki, "Knowledge Economics: Minitrack Introduction," in 49th Hawaii International Conference on System Sciences (HICSS), Kauai, USA, 2016, p. 4103. 
[7] C. Brockmann and N. Roztocki, "The Evolution of Knowledge Economics through the Course of Time - An Analysis of the HICSS Minitrack," in 47th Hawaii International Conference on Systems Sciences (HICSS), Big Island, USA, 2014.

[8] C. Brockmann, An Approach to Design the Business Model of an ERP Vendor. Berlin: GITO, 2014.

[9] T.H. Davenport and L. Prusak, Working Knowledge : How Organizations Manage What They Know. Boston: Harvard Business School Press, 1998.

[10] D.C. Colander, Economics. Boston: McGraw-Hill, 2006.

[11] N.G. Mankiw, Principles of Economics. Fort Worth: Harcourt College Publishers, 2001.

[12] R.P.M. Bade, Foundations of Microeconomics. Boston: Addison Wesley, 2002.

[13] M.E. Jennex, "Productivity Impacts from Knowledge Management," in 11th Americas Conference on Information Systems (AMCIS), Omaha, USA, 2005.

[14] M.E. Jennex, S. Smolnik, and D. Croasdell, "Towards Defining Knowledge Management Success," in 40th Annual Hawaii International Conference on System Sciences (HICSS), Big Island, USA, 2007, pp. 193c-193c.

[15] M.E. Jennex and S. Zyngier, "Security as a Contributor to Knowledge Management Success," Information Systems Frontiers, 9(5), pp. 493 - 504, 2007.

[16] J. Kowal and N. Roztocki, "Job Satisfaction of IT Professionals in Poland: Does Business Competence Matter?," Journal of Business Economics and Management, 16(5), pp. 995-1012, 2015.

[17] D. Dobija, K.M. Klimczak, N. Roztocki, and H.R. Weistroffer, "Information Technology Investment Announcements and Market Value in Transition Economies: Evidence from Warsaw Stock Exchange," The Journal of Strategic Information Systems, 21(4), pp. 308-319, 2012.

[18] T. Chung, T.-P. Liang, C.-H. Peng, and D.-N. Chen, "Knowledge Creation and Financial Firm Performance: Mediating Processes from an Organizational Agility Perspective," in 45th Hawaii International Conference on System Sciences (HICSS), Wailea, USA, 2012, pp. 36223631.

[19] P. Rai, "Matching Up the Gap between Perceived Importance and Knowledge for IT Skills among Australian Accountants," in 45th Hawaii International Conference on System Sciences (HICSS), Wailea, USA, 2012, pp. $3632-$ 3640 .

[20] E.M. Trauth, "Barriers to Knowledge Acquisition, Transfer and Management in Regional Knowledge
Economy Development," in 46th Hawaii International Conference on System Sciences (HICSS), Wailea, USA, 2012, pp. 3612-3621.

[21] J. Bahrs, G. Vladova, and N. Gronau, "To Share or Not to Share? Risks and Benefits of the External Knowledge Transfer," in 46th Hawaii International Conference on System Sciences (HICSS), Wailea, USA, 2013, pp. 35253533.

[22] F. Loeser, K. Erek, F. Limbach, and R. Zarnekow, "Shared Domain Knowledge in Strategic Green IS Alignment: An Analysis from the Knowledge-Based View," in 46th Hawaii International Conference on System Sciences (HICSS), Wailea, USA, 2013, pp. 3515-3524.

[23] J. Prpic and P. Shukla, "The Theory of Crowd Capital," in 46th Hawaii International Conference on System Sciences (HICSS), Wailea, USA, 2013, pp. 3505-3514.

[24] H. Thies and K. Stanoevska-Slabeva, "Enhancing the Quality of Information in Inter-organizational Environmental Reporting Information Systems," in 46th Hawaii International Conference on System Sciences (HICSS), Wailea, USA, 2013, pp. 3495-3504.

[25] J. Prpic and P. Shukla, "The Contours of Crowd Capability," in 47th Hawaii International Conference on Systems Sciences (HICSS), Waikoloa, USA, 2014.

[26] A. Sharif, M.M. Kamal, and Z. Irani, "Visualisation of Knowledge Mapping for Information Systems Evaluation: A Manufacturing Context," in 47th Hawaii International Conference on Systems Sciences (HICSS), Waikoloa, USA, 2014.

[27] C. Brockmann and N. Roztocki, "Topics on Knowledge Management: An Empirical Insight into Articles Published in the International Journal of Knowledge Management," in 48th Hawaii International Conference on Systems Sciences (HICSS), Kauai, USA, 2015.

[28] M. Hilbert, "Toward a Theory of Knowledge Economics: An Information Systems Approach," in 48th Hawaii International Conference on Systems Sciences (HICSS), Kauai, USA, 2015.

[29] A. Kees, "Knowledge Economics Based Upon a 4Pillar-Model - A Field Report," in 48th Hawaii International Conference on Systems Sciences (HICSS), Kauai, USA, 2015.

[30] K.A. Al-Busaidi, "Fostering GCC's Knowledge Economy through ICT: Research in Progress," in Proceedings of the 2016 49th Hawaii International Conference on System Sciences (HICSS): IEEE Computer Society, 2016, pp. 4104-4112.

[31] J. Kowal and A. Gurba, "Mobbing and Burnout in Emerging Knowledge Economies: An Exploratory Study in 
Poland," in 49th Hawaii International Conference on System Sciences (HICSS), Kauai, USA, 2016, pp. 4123-4132.

[32] R. Peinl, E. Sultanow, and C. Brockmann, "Towards Mobile Modeling of Knowledge and Business Processes," in Proceedings of the 2016 49th Hawaii International Conference on System Sciences (HICSS): IEEE Computer Society, 2016, pp. 4133-4142.

[33] I. Nonaka and T. Hirotaka, The Knowledge-Creating Company : How Japanese Companies Create the Dynamics of Innovation. New York: Oxford University Press, 1995.

[34] I. Nonaka, "A Dynamic Theory of Organizational Knowledge Creation," Organization Science, 5(1), pp. 1437, 1994.

[35] M. Alavi and D.E. Leidner, "Review: Knowledge Management and Knowledge Management Systems: Conceptual Foundations and Research Issues," MIS Quarterly, 25(1), pp. 107-136, 2001.

[36] W.W. Powell and K. Snellman, "The Knowledge Economy," Annual Review of Sociology, 30, pp. 199-220, 2004.

[37] F.A. Hayek, "The use of knowledge in society," The American Economic Review, 35(4), pp. 519 - 530, 1945.

[38] I. Nonaka and R. Toyama, "The Knowledge-Creating Theory Revisited: Knowledge Creation as a Synthesizing Process," Knowledge Management Research \& Practice, 1(1), pp. 2 - 10, 2003.

[39] M. Polanyi, The Tacit Dimension. Garden City, N.Y.: Doubleday, 1966.

[40] V.K. Goel, E. Koryukin, M. Bhatia, and P. Agrawal, "Innovation Systems - World Bank Support of Science and Development," World Bank Working Paper No. 32, Ed. Washington, D.C.: The World Bank, 2004.

[41] D. Francis, "A reference model of innovation capability and implications for organisational development," in CI Net, Brighton, UK, 2005, pp. 224-235.

[42] R. Gabryelczyk, A. Jurczuk, and N. Roztocki, "Business Process Management in Transition Economies: Current Research Landscape and Future Opportunities," in 22th Americas Conference on Information Systems (AMCIS), 2016.

[43] T.W. Schultz, "Investment in Human Capital," American Economic Review, 51(1), pp. 1-17, 1961.

[44] J. Kowal and N. Roztocki, "Do Organizational Ethics Improve IT Job Satisfaction in the Visegrád Group Countries? Insights from Poland," Journal of Global Information Technology Management, 18(2), pp. 127-145, 2015.
[45] T.M. Amabile, R. Conti, H. Coon, J. Lazenby, and M. Herron, "Assessing the Work Environment for Creativity," Academy of Management Journal, 39(5), pp. 1154-1184, 1996.

[46] N. Roztocki and H.R. Weistroffer, "From the Special Issue Editors: Information Technology in Transition Economies," Information Systems Management, 28(3), pp. 188-191, 2011.

[47] F.W. Taylor, The Principles of Scientific Management, 1911.

[48] R.H. Coase, "The Nature of the Firm," Economica, 4(16), pp. 386 - 405, 1937.

[49] A.N. Kolmogorov, "Interpolation and extrapolation of stationary random sequences," Izv. Akad. Nauk SSSR Ser. Mat., 5(1), pp. 3-14, 1941.

[50] N. Roztocki and H.R. Weistroffer, "Information and Communication Technology in Transition Economies: An Assessment of Research Trends," Information Technology for Development, 21(3), pp. 330-364, 2015.

[51] N. Roztocki and H.R. Weistroffer, "Information Technology Success Factors and Models in Developing and Emerging Economies " Information Technology for Development, 17(3), pp. 163-167, 2011.

[52] J. Kowal and N. Roztocki, "Information and Communication Technology Management for Global Competitiveness and Economic Growth in Emerging Economies," The Electronic Journal of Information Systems in Developing Countries, 57, 2013. 